\title{
Article \\ Comparison of Ni-Based Self-Fluxing Remelted Coatings for Wear and Corrosion Applications
}

\author{
Norbert Kazamer ${ }^{1, *(\mathbb{D}}$, Roxana Muntean ${ }^{2} \mathbb{D}$, Petru Cristian Vălean ${ }^{2}$, Dragoș Toader Pascal ${ }^{1}$, Gabriela Mărginean ${ }^{3}$ \\ and Viorel-Aurel Șerban ${ }^{2}$
}

check for updates

Citation: Kazamer, N.; Muntean, R.; Vălean, P.C.; Pascal, D.T.; Mărginean, G.; Serban, V.-A. Comparison of Ni-Based Self-Fluxing Remelted Coatings for Wear and Corrosion Applications. Materials 2021, 14, 3293. https://doi.org/10.3390/ma14123293

Academic Editor: Frank Czerwinski

Received: 24 May 2021

Accepted: 11 June 2021

Published: 14 June 2021

Publisher's Note: MDPI stays neutral with regard to jurisdictional claims in published maps and institutional affiliations.

Copyright: (c) 2021 by the authors. Licensee MDPI, Basel, Switzerland. This article is an open access article distributed under the terms and conditions of the Creative Commons Attribution (CC BY) license (https:/ / creativecommons.org/licenses/by/ $4.0 /)$.
1 Westphalian Energy Institute, Westphalian University of Applied Sciences Gelsenkirchen Bocholt Recklinghausen, Neidenburgerstr. 43, 45897 Gelsenkirchen, Germany; dragos.pascal88@gmail.com

2 Department of Materials and Manufacturing Engineering, University Politehnica of Timișoara, Piața Victoriei 2, 300006 Timișoara, Romania; roxana.muntean@upt.ro (R.M.); petru_valean@yahoo.com (P.C.V.); viorel.serban@upt.ro (V.-A.Ș.)

3 Department of Materials Science and Testing, Westphalian University of Applied Sciences Gelsenkirchen Bocholt Recklinghausen, Neidenburgerstr. 43, 45897 Gelsenkirchen, Germany; gabriela.marginean@w-hs.de * Correspondence: norbert.kazamer@w-hs.de; Tel.: +49-209-959-650-89

\begin{abstract}
The present study investigates the possibility to apply a vacuum furnace thermal posttreatment as an alternative solution for flame sprayed NiCrBSi wear and corrosion-resistant coatings, deposited on a low alloyed structural steel. The controlled atmosphere offers advantages regarding the fusion of the coating, porosity reduction, and degassing. An improvement of the applied heating-cooling cycle was performed through the variation of time and temperature. The best performing samples were selected by comparing their porosity and roughness values. The chosen samples were subsequently characterized regarding their microstructure, microhardness, sliding wear, and corrosion behavior. The experimental work confirms that the use of a vacuum remelting post-process reduces the porosity below $1 \%$ and leads to the formation of a larger quantity of hard boron-containing phases, promoting a significant decrease of the wear rate, while maintaining a good corrosion behavior.
\end{abstract}

Keywords: flame-spraying; NiCrBSi; vacuum furnace; remelting; microstructure; phase composition; wear resistance; corrosion behavior

\section{Introduction}

NiCrBSi coatings in various chemical compositions are predominantly used in paper, petrol, hot working punches, heat exchangers, or glass mold industries [1-4]. Containing borides and carbides, distributed within the microstructure, the Ni-based alloys show excellent resistance during wear tests [3]. The superior corrosion behavior is attributed to the presence of chromium, as an alloying element in the coating. These compositions are often used as a substitute for hard chromium coatings, well known for environmental issues [5]. Nevertheless, despite the technological advances, flame sprayed Ni-based alloy coatings generally manifest moderate adhesion to the substrate, high porosity, unmelted particles, and unwanted oxides [6]. Subsequently, a fusing process is imperatively necessary to eliminate the undesired microstructural features resulted from spraying technology and consequently to improve the properties and characteristics of such coatings [6]. The presence of boron and silicon lowers the melting temperature, making this alloy a suitable candidate for applying remelting processes [2].

The best known technologies for the post-treatment are flame, furnace, laser remelting, and induction [2,6-9]. The most commonly applied technology is flame remelting because of the low cost and ease of handle. However, the relative low control of the process, risk of heat-affected zones creation, and uncontrolled atmosphere make this process, in certain situations, undesirable to use [10]. Lately, vacuum furnaces have been considered for 
heat treatments, as they can offer service stability due to the nature of the processing environment, possibility of handling parts with complex geometries, and relatively low costs, with a short recoupment period [11]. A controlled atmosphere helps to significantly improve the quality of the surface coating by realizing gas extraction, eliminating pores, and offering reproducible results [12,13].

The aim of this research work is to investigate the influence of vacuum furnace post-treatment of Ni-based thermally sprayed coatings. The novelty of the research is represented by the remelting process of the proposed alloy, in a vacuum furnace, correlated with a comparison with the classical method of flame remelting, in respect to its resistance during different tests. The microstructure, phase composition, microhardness, porosity, adhesion of both flame remelted (FR), and vacuum remelted (VR) coatings were investigated, and the wear and corrosion behavior were evaluated according to the specific standards.

\section{Materials and Methods}

\subsection{Feedstock Powder and Methods for Characterization}

The SEM (scanning electron microscopy, Philips XL 30, Eindhoven, The Netherlands) micrograph shown in Figure 1a presents the spheroidized shape and the size of approximately $90 \mu \mathrm{m}$ of the NiCrBSi powder, while Figure $1 \mathrm{~b}$ demonstrates, based on the EDX analysis, the high Ni content of the proposed alloy. The chemical composition of the powder can be seen in Table 1. The EDX spectrum (EDAX AMETEK, Mahwah, NJ, USA) highlights the carbide forming element, $\mathrm{Cr}$, which contributes to an increase in the wear resistance, and $\mathrm{Si}$, which promotes the deoxidation and wettability of the coating during the heat treatment. The spheroidized morphology of the powder is a favorable aspect during the deposition process, assuring the flowability of the particles.

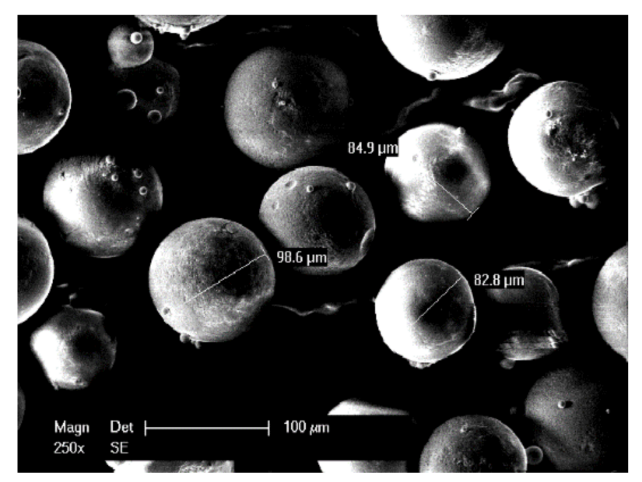

(a)

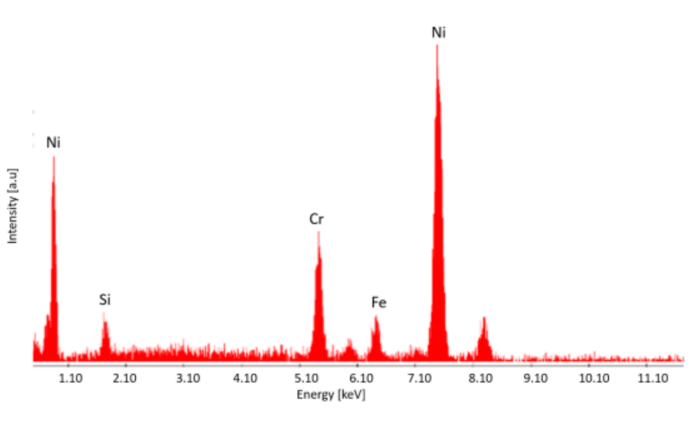

(b)

Figure 1. SE micrograph (a) and EDX spectrum (b) of the NiCrBSi powder.

Table 1. Chemical composition of the powder.

\begin{tabular}{cccccc}
\hline $\begin{array}{c}\mathbf{N i} \\
(\mathbf{\%})\end{array}$ & $\begin{array}{c}\mathrm{Cr} \\
(\mathbf{\%})\end{array}$ & $\begin{array}{c}\mathbf{B} \\
\mathbf{( \% )}\end{array}$ & $\begin{array}{c}\mathrm{Si} \\
\mathbf{( \% )}\end{array}$ & $\begin{array}{c}\mathbf{F e} \\
(\mathbf{\%})\end{array}$ & $\begin{array}{c}\mathbf{C} \\
(\mathbf{\%})\end{array}$ \\
\hline balance & 6 & 1 & 4 & 1.5 & 0.3 \\
\hline
\end{tabular}

\subsection{Coating Deposition and Remelting}

The flame spraying of the NiCrBSi coatings was performed with the parameters displayed in Table 2 by the partner company Karl Schumacher GmbH, Germany. The work piece was subjected to degreasing and grit-blasting, to obtain a good tensile adhesive strength and prevent strong substrate oxidation [14]. 
Table 2. Deposition parameters.

\begin{tabular}{cc}
\hline Parameters & Materials/Conditions/Values \\
\hline Surface roughening & - \\
Surface roughening method & Grit blasting \\
Roughening material & Chilled iron grit \\
min. $75 \mu \mathrm{m}$ & Metatherm \\
Surface roughness after roughening & - \\
Flame spraying gun producer & Acetylene $\left(\mathrm{C}_{2} \mathrm{H}_{2}\right)$ \\
Flame generation & Oxygen $\left(\mathrm{O}_{2}\right)$ \\
Fuel gas & $1: 2$ \\
Secondary gas & $\approx 105^{\circ} \mathrm{C}$ \\
Flame stoichiometry $\mathrm{C}_{2} \mathrm{H}_{2}: \mathrm{O}_{2}$ & $\approx 2850{ }^{\circ} \mathrm{C}$ \\
Substrate temperature & $\approx 1100^{\circ} \mathrm{C}$ \\
Spraying temperature & $100 \mathrm{~m} \mathrm{~s}^{-1}$ \\
Fusion temperature & - \\
Particle velocity & $2.5 \mathrm{~kg} \mathrm{~h}^{-1}$ \\
Coating deposition & $120 \mathrm{~mm}^{-1}$ \\
Powder feed rate & Purified air \\
Stand-off distance & Pranslation over the samples \\
Propelling gas &
\end{tabular}

Preceding the remelting process, a careful thermal analysis of the powder was performed with the aid of a Netzsch STA 449 F1, instrument, NETZSCH, Selb, Germany. On the DTA (differential thermal analysis) curve, represented in Figure 2, a melting interval between $1013{ }^{\circ} \mathrm{C}$ and $1075{ }^{\circ} \mathrm{C}$ has been identified. In order to achieve densification of the coating and to prevent the liquid-phase flow during the thermal post-treatment, it is important to choose a temperature with $10^{\circ} \mathrm{C}-20^{\circ} \mathrm{C}$ under the liquidus temperature, as determined from the thermal analysis [15].

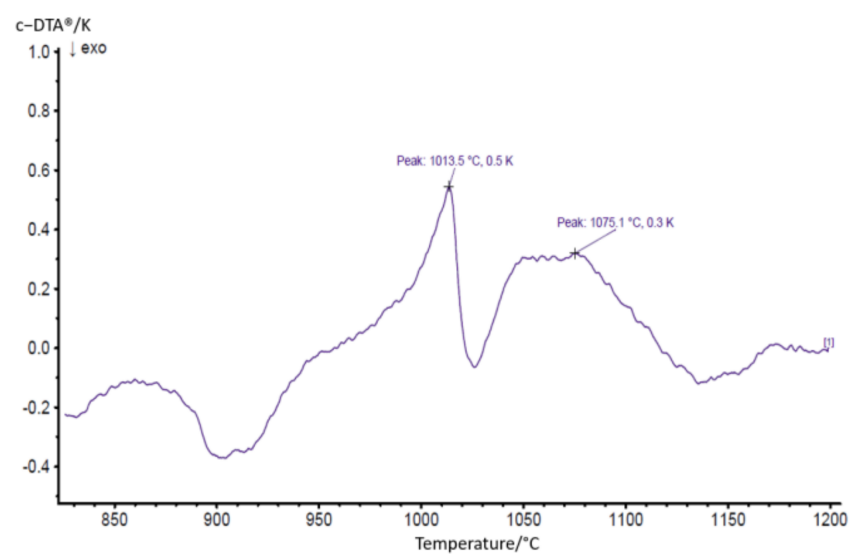

Figure 2. DTA curve highlighting the solidus and liquidus temperature of the NiCrBSi powder.

The remelting process of the coatings was performed with the help of a HITERM 80-200, HITEC Materials, Karlsruhe, Germany, vacuum furnace. Figure 3 represents the cyclogram of the applied thermal treatment, where the ramps and holding times were set corroborating the DTA data with empirically adjusted parameters. The program has three-interval heating ramps, the first being performed with $10^{\circ} \mathrm{C} \min ^{-1}$ up to $200{ }^{\circ} \mathrm{C}$, where water and other possible compounds can be eliminated from the sample's surface. The second heating ramp is performed with $10^{\circ} \mathrm{C} \mathrm{min}^{-1}$, until $950{ }^{\circ} \mathrm{C}$. At this temperature, the sample is under the melting range of the matrix, but high enough to soak the material. A slow heating step at $5{ }^{\circ} \mathrm{C} \mathrm{min}-1$ has been applied, followed by a holding of $20 \mathrm{~min}$. at $1050{ }^{\circ} \mathrm{C}$, as resulted from the DTA data. Furthermore, a slow cooling until $950{ }^{\circ} \mathrm{C}$ was performed to avoid the occurrence of internal stresses. The last cooling ramp was set at $10{ }^{\circ} \mathrm{C} \mathrm{min}-1$ until the ambient temperature of $23^{\circ} \mathrm{C}$ was reached. 


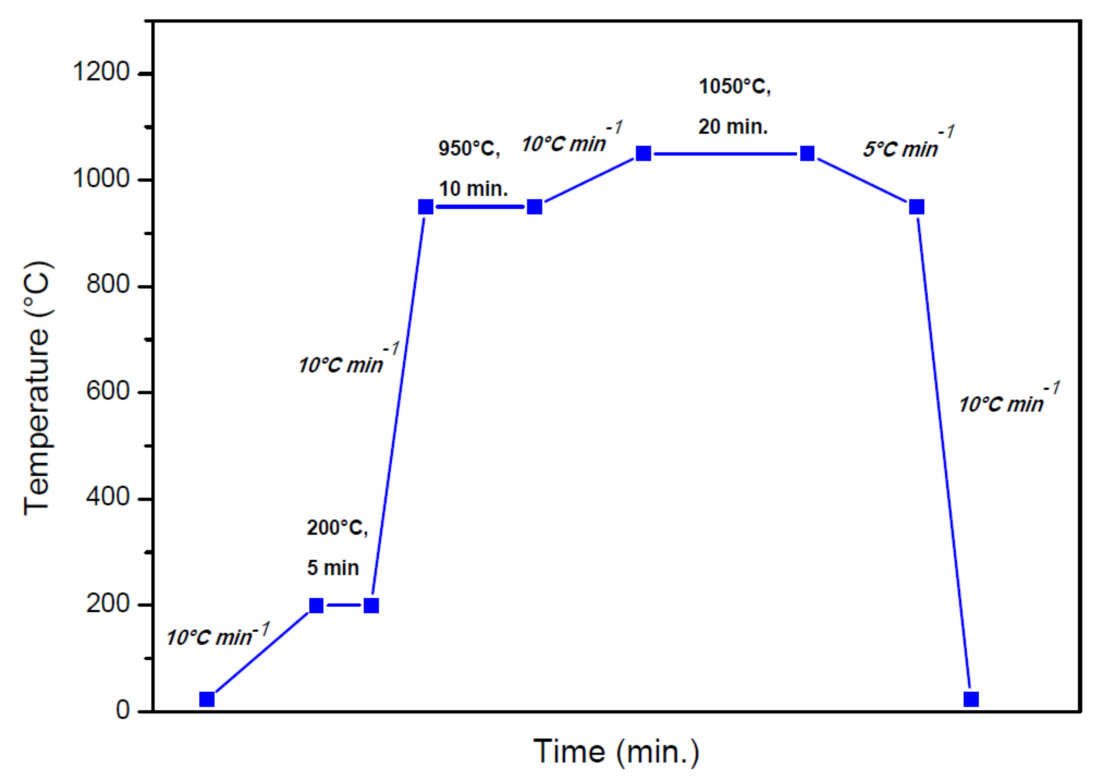

Figure 3. Vacuum furnace heating/cooling cycle.

The reference specimens for the present study consisted of identical thermal assprayed samples, flame remelted with the Metatherm, gun using the same gas stoichiometry of $\mathrm{C}_{2} \mathrm{H}_{2}: \mathrm{O}_{2}$ 1:2. Due to the tendency of energy dissipation, the torch was first moved near the coated samples and the material was preheated at $500{ }^{\circ} \mathrm{C} \pm 2{ }^{\circ} \mathrm{C}$. The flame remelting was performed at a temperature in the melting range of the material, as determined with the DTA analysis, by moving the gun as a translation over the samples for approximately $10 \mathrm{~min}$. The temperature was monitored using an infra-red thermometer.

\subsection{Sample Roughness Measurement and Porosity Estimation}

The sample roughness measurements were carried out in three areas of each specimen with the help of a dedicated software, using a CLSM Keyence VK-X microscope, Japan. For this analysis, the two most important parameters that were considered for the characterization of the surface roughness were $R a$ and $R z$, as defined by Whitehouse [16]. The porosity of the coatings was estimated on three different regions from the optical micrographs, using the open source image analysis software, ImageJ (version 1.53j).

\subsection{Microstructure, Hardness, Adhesion, Wear, and Corrosion Testing}

Several tests were undertaken to investigate the quality of the coating. The morphology, microstructure, and chemical composition were studied using a XL 30 SEM, Philips, Eindhoven, The Netherlands, combined with its EDX detector. The micrographs were acquired at a $10 \mathrm{~mm}$ working distance and a cathode voltage of $25 \mathrm{kV}$. The phase composition was analyzed using the X'Pert X-ray diffractometer, Philips, Eindhoven, The Netherlands. The measurements were performed in the reflection mode, with $\mathrm{CuK} \alpha$ as the radiation source, at $40 \mathrm{kV}$ and $40 \mathrm{~mA}$, scan rate of $0.01^{\circ} 2 \theta \mathrm{min}^{-1}$, and an angular resolution of $0.005^{\circ}$ $2 \theta$. The hardness evaluation of the coatings was performed using a Zwick/Roell ZHV $\mu-S$ Vickers microhardness tester, Ulm, Germany, with a total load of $2.94 \mathrm{~N}$ (HV0.3), in five different indentations on each specimen. As similarly tested by Tunis et al. [16], the adhesion at the interface was examined through three sets of Brinell macroindentations, under three different loads, with a maximum load of $1838 \mathrm{~N}$ (HBW 2.5/187.5). Pin-on-disk tests were realized on a CSM Instruments Tribometer, Needham Heights, MA, USA, and the applied parameters are shown in Table 3. The tests were undertaken to measure the coefficient of friction, and subsequently, the wear rate coefficient of the sample was calculated using the Archard equation:

$$
k=\frac{W_{v}}{F_{N} \cdot S}
$$


where the wear rate coefficient $k\left(\mathrm{~mm}^{3} \mathrm{~N}^{-1} \mathrm{~m}^{-1}\right)$ is the wear volume $W_{V}\left(\mathrm{~mm}^{3}\right)$ divided by normal load $F_{N}(\mathrm{~N})$ multiplied with the sliding distance $s(\mathrm{~m})$ [17]. The counterbody $(6 \mathrm{~mm}$ WC-Co ball) worn volume $W_{V}$ was considered as well. The corrosion tests were carried out in a three-electrode cell, using $3.5 \% \mathrm{NaCl}$ standardized solution, at room temperature. The applied potential varied between -1000 and $+500 \mathrm{mV}$ versus Saturated Calomel Electrode (SCE), with a scan rate of $0.16 \mathrm{mV} \mathrm{s}^{-1}$. The tests were realized using a VoltaLab PGP201 Potentiostat/Galvanostat, Radiometer Analytical SAS, Lyon, France. For reproducibility, each investigation was performed three times.

Table 3. Pin-on-disk test parameters.

\begin{tabular}{ccccccc}
\hline Static Counterpart & $\begin{array}{c}\text { Radius } \\
(\mathbf{m m})\end{array}$ & $\begin{array}{c}\text { Linear Speed } \\
\left(\mathbf{c m ~ s}^{-\mathbf{1}}\right)\end{array}$ & $\begin{array}{c}\text { Normal Load } \\
(\mathbf{N})\end{array}$ & Laps & Total Distance (m) & Test Duration (s) \\
\hline WC-Co ball & 3 & 15 & 10 & 50,000 & 947 & 6300 \\
\hline
\end{tabular}

\section{Results}

\subsection{Sample Roughness and Porosity Calculation}

It is important to consider the surface roughness and porosity of the functional coatings. At high porosity values, the penetration of water molecules, oxygen, or other unwanted compounds into isolated regions of inhomogeneities is more likely than at smaller values, resulting in unsatisfactory corrosion behavior of the material [18]. During the optimization process in the vacuum furnace, it was noticed that the samples kept for a longer period of time at $1050{ }^{\circ} \mathrm{C}$, present a shinier and smoother surface, being also an important indicator that the surface is completely sealed. The roughness measurements showed that both $R a$ and $R z$ average values, which can be found in Table 4, for the VR samples are approximately $30 \%$ lower in comparison with those of the FR coatings. Regarding the porosity, also presented in Table 4, it is interesting to notice that its value decreased from $7.55 \%$ in the case of the flame-sprayed coatings to $0.6 \%$ for the flame remelting process and it reached a value of $0.15 \%$ for the VR samples. The porosity of the as-sprayed coatings is shown in Figure $4 a$, and for the post-treated samples is highlighted in Figure $4 b$,c. The wetting properties and the surface tension of the phases can be controlled through the content of silicon and boron [19], directly affecting the porosity and acting as fluxing agents. The decrease of porosity in the case of the VR sample can be attributed to the capacity of the furnace to precisely control and maintain the temperature of the sample at a few degrees lower than the liquidus point of the alloy, which leads to a proper wetting of the substrate surface, a good degassing, and closure of voids.

Table 4. Roughness and porosity average measurements of the as-sprayed, FR and VR samples.

\begin{tabular}{cccc}
\hline Sample & $\begin{array}{c}\boldsymbol{R} \boldsymbol{a} \\
(\boldsymbol{\mu \mathrm { m } )}\end{array}$ & $\begin{array}{c}\boldsymbol{R z} \\
(\boldsymbol{\mu \mathrm { m } )}\end{array}$ & $\begin{array}{c}\text { Porosity } \\
(\mathbf{\%})\end{array}$ \\
\hline As-sprayed & 18.82 & 99.34 & 7.55 \\
FR & 7.32 & 48.81 & 0.6 \\
VR & 5.02 & 36.63 & 0.15 \\
\hline
\end{tabular}

The microstructure was carefully analyzed for both remelted specimens. The EDX spot analysis was focused on identifying only the chemical elements $\mathrm{Ni}, \mathrm{Cr}, \mathrm{Si}$, and $\mathrm{Fe}$, whereas $\mathrm{B}$ and $\mathrm{C}$ are too light, and their weight percentage is too low to be detected with this method. It is important to consider that the cooling rate of the particles during the thermal spraying processes is higher than $10^{6} \mathrm{~K} \mathrm{~s}^{-1}$, causing metastable microstructures [20]. The phase composition determined by means of XRD analysis consists, in both cases, of $\gamma-\mathrm{Ni}_{2} / \mathrm{Ni}_{3} \mathrm{~B}$ solid solution and further phases like $\mathrm{CrB}$ and $\mathrm{Cr}_{6} \mathrm{Ni}_{16} \mathrm{Si}_{7}$. Similar $\gamma-\mathrm{Ni} / \mathrm{Ni}_{3} \mathrm{~B}$ phases were already previously reported in the literature [21-23]. Corroborating the XRD with the EDX spot analysis, the matrix marked with $\mathrm{A}$ in Figure $5 \mathrm{a}, \mathrm{b}$ consists of the $\gamma-\mathrm{Ni} / \mathrm{Ni}_{3} \mathrm{~B}$ phase, the darker region marked with $\mathrm{B}$ shows the primary crystals of $\mathrm{CrB}$, while the lighter 
region of $\mathrm{C}$ represents the $\mathrm{Cr}_{6} \mathrm{Ni}_{16} \mathrm{Si}_{7}$. It has been suggested that $\mathrm{CrB}$ forms during the primary solidification [6] if the content of $B$ in the powder exceeds $0.8 \%$ [24]. The interface region of the coatings, Figure $6 \mathrm{a}, \mathrm{b}$, shows no evidence of delamination or cracks. A higher concentration of the $\mathrm{CrB}$ can be seen in the region of the interface. That is caused by the fact that the phase has a higher density than that of the molten phase, which brings the hard phase through gravity towards the coating-substrate area. In the region of the interface, a dilution of $\mathrm{Ni}$ appears towards the substrate. Looking closer at the XRD spectra, presented in Figure $7 \mathrm{a}, \mathrm{b}$, it can be seen that the quantity of $\mathrm{Ni}$ and $\mathrm{Cr}_{6} \mathrm{Ni}_{16} \mathrm{Si}_{7}$ phases is similar, while the amount of $\mathrm{CrB}$ increases in the VR sample. The impact of the phase quantity directly affected the coating behavior during the sliding wear tests.

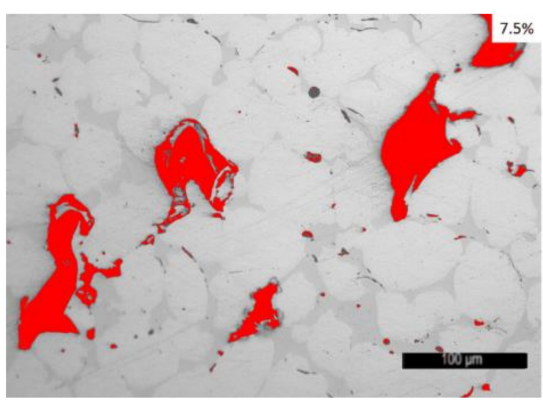

(a)

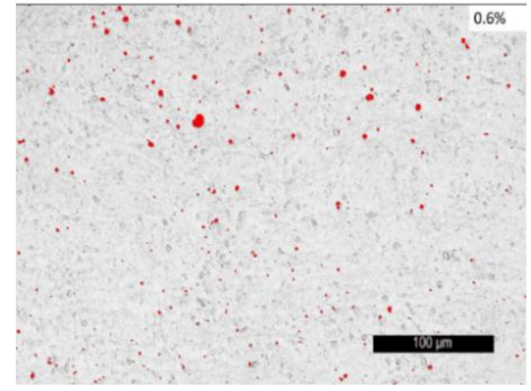

(b)

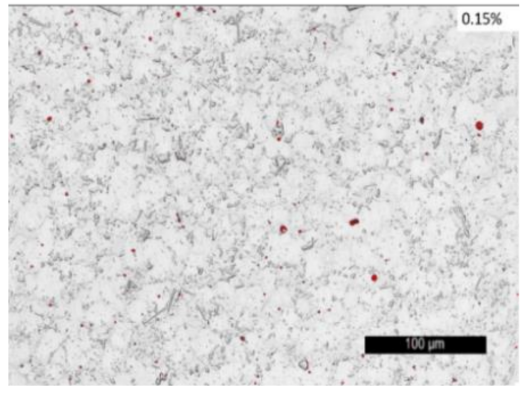

(c)

Figure 4. Porosity values of the, as-sprayed (a), FR (b), and VR (c) samples.

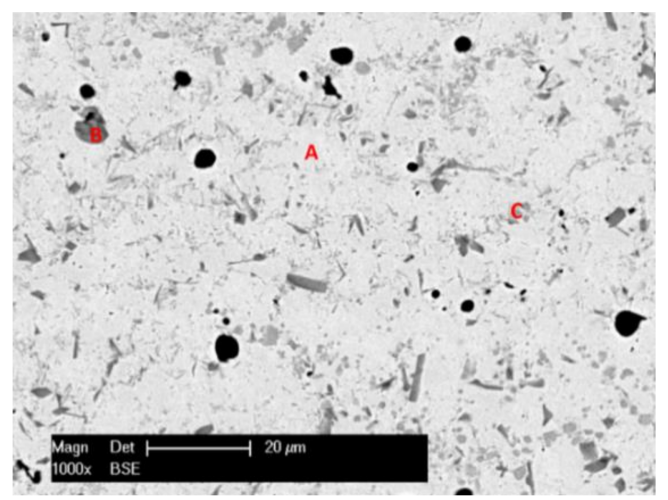

(a)

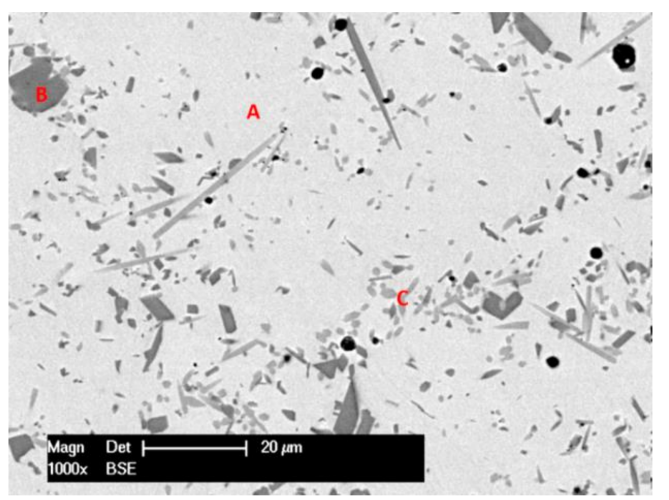

(b)

Figure 5. BSE micrograph of a detail of the FR (a) and VR (b) coatings.

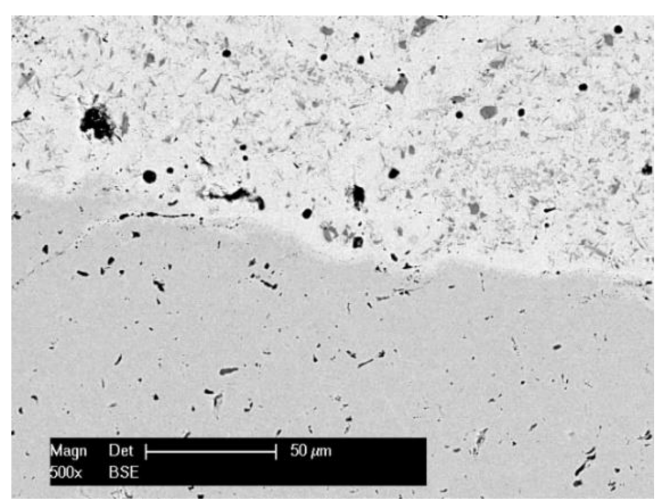

(a)

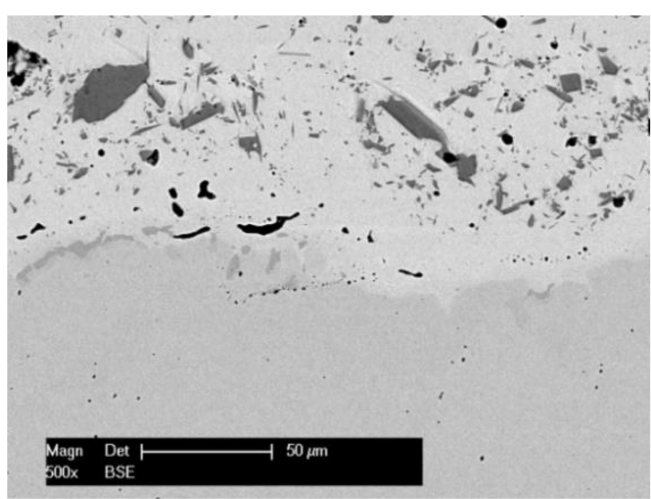

(b)

Figure 6. BSE micrograph of the interface at the FR (a) and VR (b) samples. 


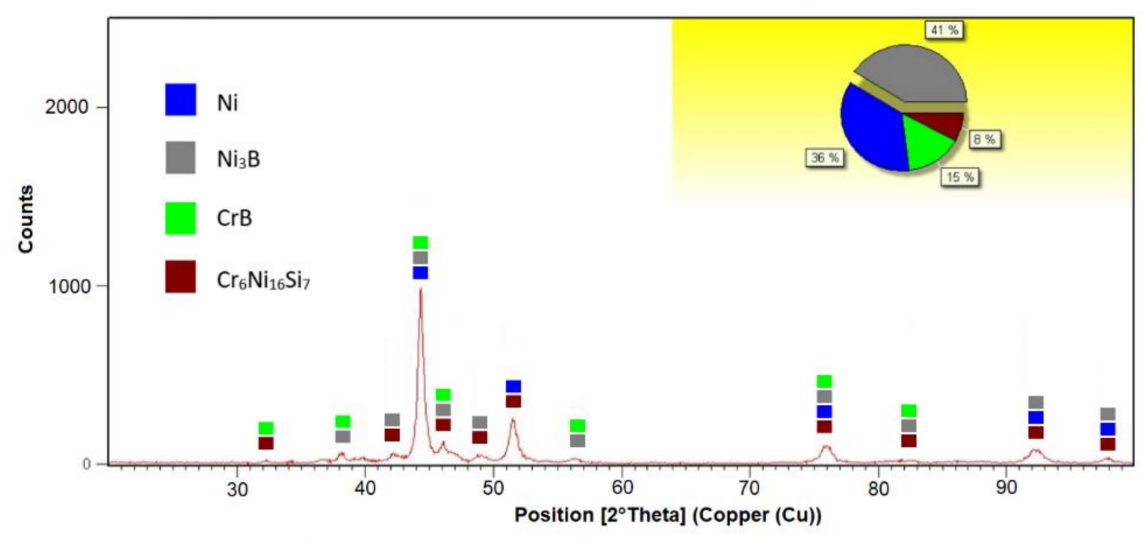

(a)

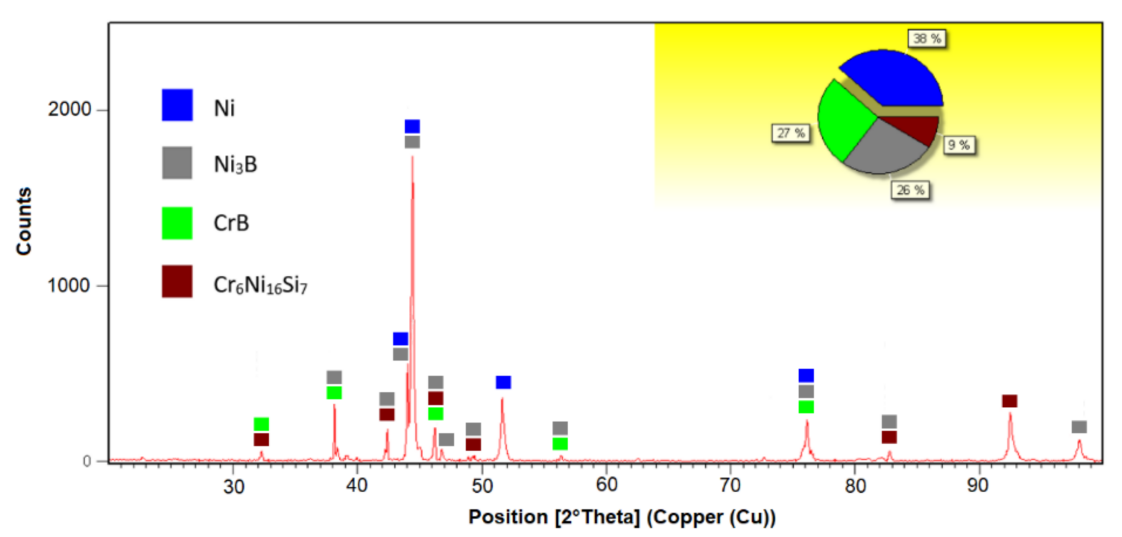

(b)

Figure 7. XRD spectra of the FR (a) and VR (b) samples.

\subsection{Hardness and Adhesion}

The microhardness of the coatings was evaluated by realizing one set of imprints consisting of five indentations along the coating on each specimen and the distribution of the values is presented in Figure 8. Although the as-sprayed coating exhibits the highest value of $809 \mathrm{HV} 0.3$, it also shows a variation of over $30 \%$ between the maximum and the minimum point of the coating hardness, the difference being accounted to the pores and material inhomogeneities. Concerning the remelted samples, the FR specimen exhibited an average value of $674 \mathrm{HV0.3,} \mathrm{while} \mathrm{the} \mathrm{VR} \mathrm{one,} \mathrm{an} \mathrm{average} \mathrm{value} \mathrm{of} 583 \mathrm{HV} 0.3$. The indentation sets manifested constant values, the difference between the extreme points not exceeding $10 \%$, aspect denoting a homogeneous coating, with a relatively uniform phase distribution. The difference in the microhardness values may lie in the cooling rates of the two remelting approaches, where the uncontrolled atmosphere of the flameremelting technology favors a much faster cooling of the samples, while the vacuum furnace installation confers a controlled cooling rate, the grain growth is continuous, hence smaller hardness values are obtained.

Regarding the adhesion of the coating to the substrate, submitting the interface under an HBW2.5/187.5 load, in Figure 9a, in the case of FR sample, some cracks can be observed in the coating, heading towards the interface, whereas in Figure 9b, for the VR sample, no cracks can be identified along the interface or in the coating, respectively. This aspect denotes that even though it presents a slightly lower hardness, the VR sample is a dense and ductile coating, not generating cracks even under a considerable load. Moreover, in the case of VR sample, the strong metallurgical bond strengthens the interface, improving the mechanical properties of the coating-substrate region. 


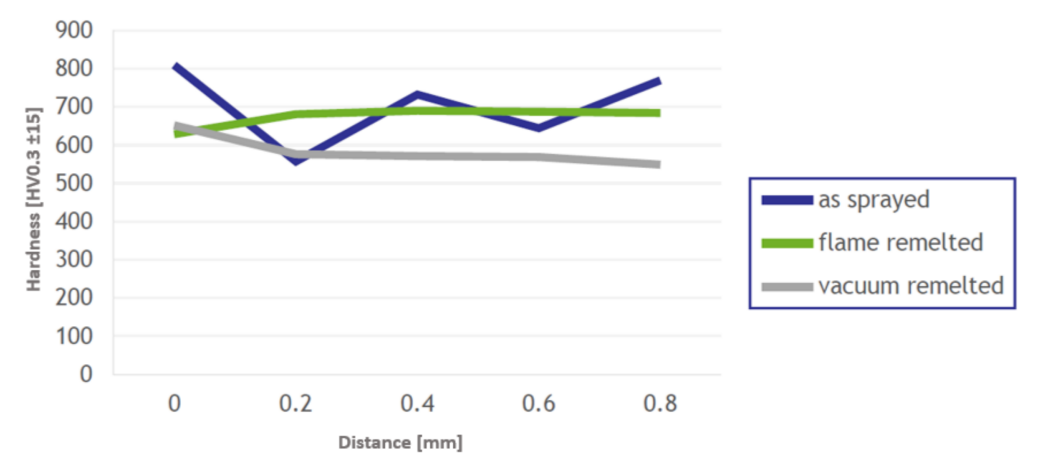

Figure 8. Graph highlighting the variation of the HV0.3 microindentations along the coating.

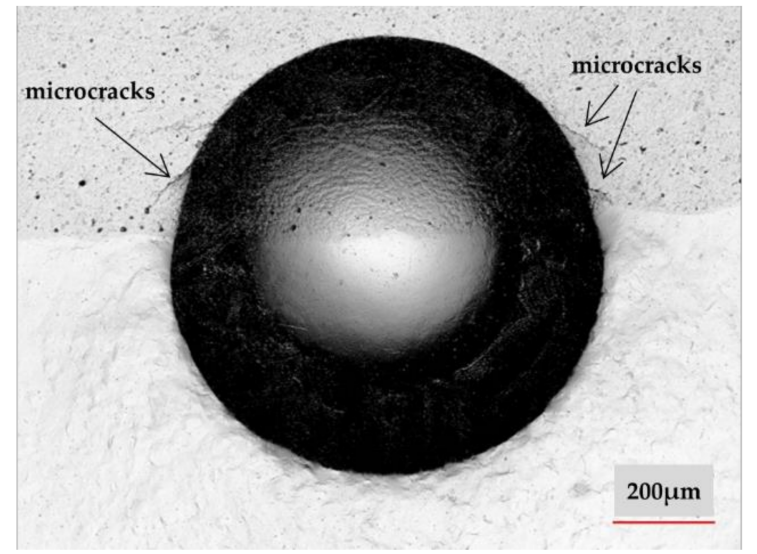

(a)

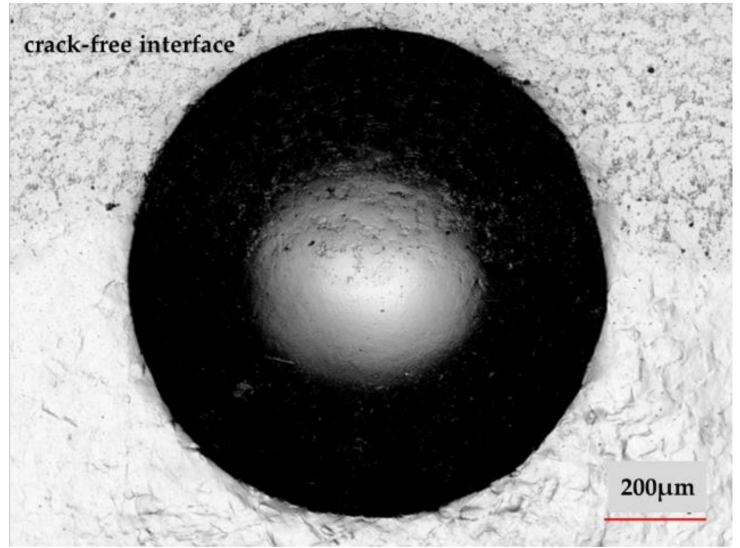

(b)

Figure 9. HBW 2.5 / 187.5 on: FR (a) and VR (b) samples at the coating/substrate interface.

\subsection{Tribology}

The tribological behavior evaluation of the coating consisted in measuring the coefficient of friction (COF) for the remelted samples (both flame and vacuum remelted) and calculating the wear rate of the samples and their counterparts. The COF, as presented in Figure 10, reached in the steady-state phase a constant mean value of approximately 0.65 , a comparable value being also reported by Wang et al. [25] for similar coatings. The only difference in the analysis of the COF is that the VR coating reached a faster steady-state slightly after around $190 \mathrm{~m}$, while the FR one reached a steady-state after a distance of approximately $250 \mathrm{~m}$.

Although the COF did not present important differences, the wear behavior of the samples was significantly different. Figure $11 \mathrm{a}, \mathrm{b}$ shows the wear tracks of the samples, with a depth of $15.25 \mu \mathrm{m}$ for the FR sample and three times smaller for the VR one. The worn cap diameter also varied, since the measured value after the dry sliding test was $809 \mu \mathrm{m}$ for the FR sample and $689 \mu \mathrm{m}$ for the VR one. The measured depths and diameters directly influence the wear rate coefficients, as presented in Table 5. The wear rates of the sample and counterpart are 50\% lower in the case of the VR specimen. This fact is due to the hard phases containing boron, namely $\mathrm{CrB}$ and $\mathrm{Ni}_{3} \mathrm{~B}$, which are present in a larger quantity in the VR specimens, aiding against the formation of deep wear tracks and consequently increasing the wear resistance of the coating. 


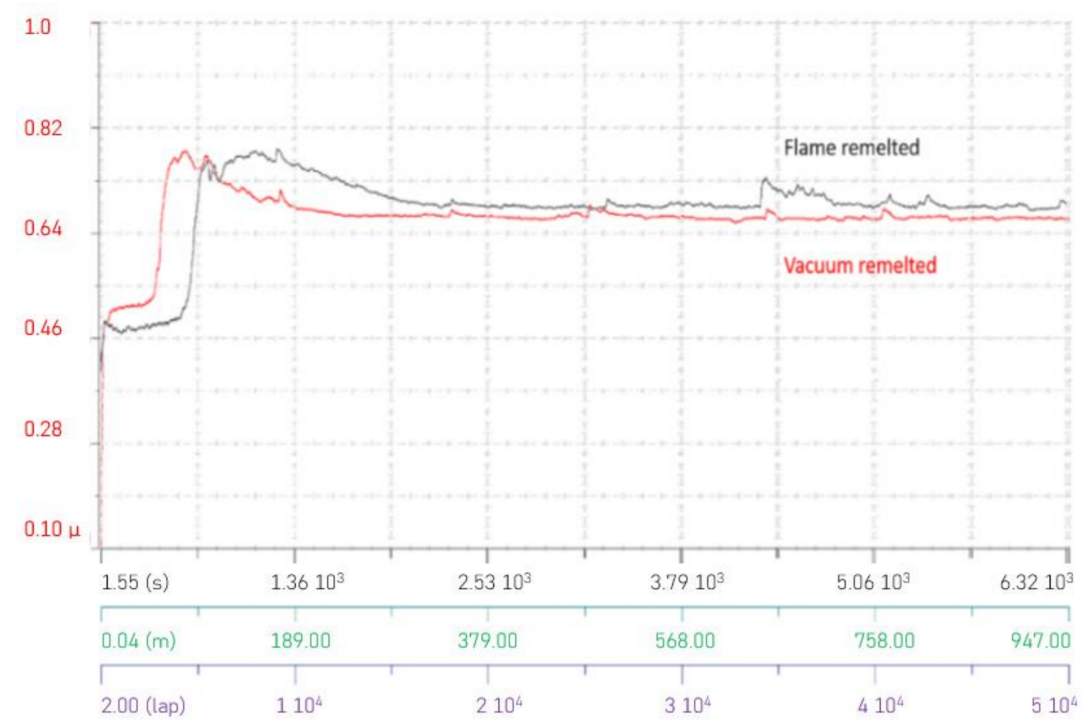

Figure 10. Graph highlighting the COF behavior.

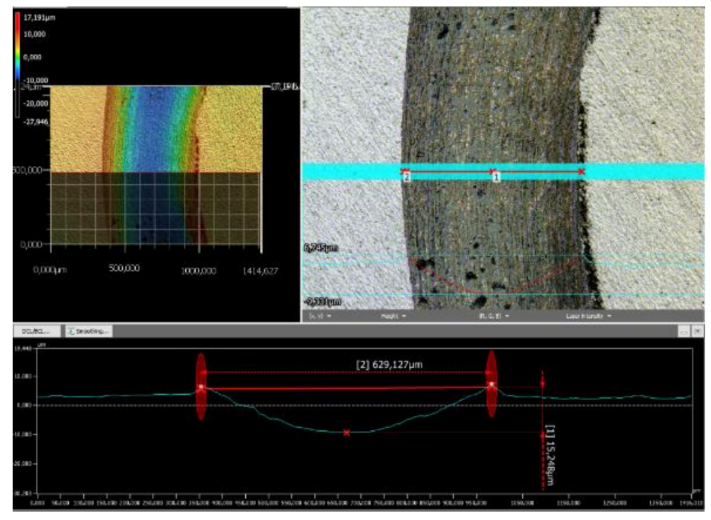

(a)

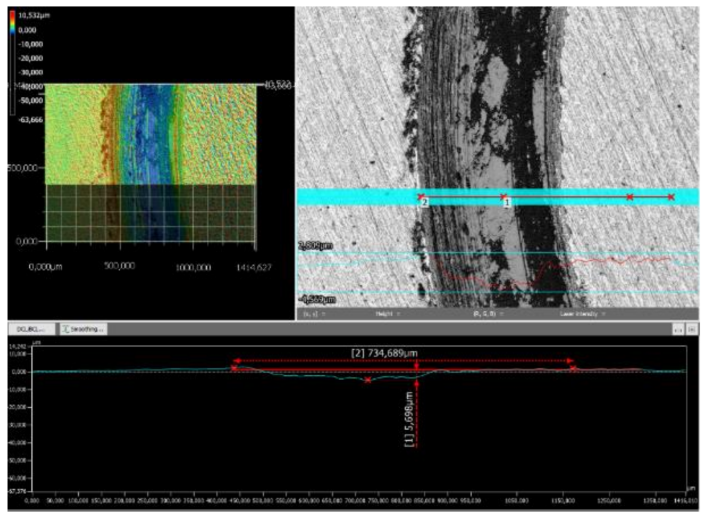

(b)

Figure 11. Sliding track of: FR (a) and VR (b) remelted samples.

Table 5. Wear rate of the samples and counterparts.

\begin{tabular}{ccc}
\hline Sample & $\begin{array}{c}\text { Sample Wear Rate } \\
\left(\mathbf{m m}^{\mathbf{3}} \mathbf{N}^{-\mathbf{1}} \mathbf{~ m}^{-\mathbf{1}}\right)\end{array}$ & $\begin{array}{c}\text { Counterpart Wear Rate } \\
\left(\mathbf{m m}^{\mathbf{3}} \mathbf{~ N}^{-\mathbf{1}} \mathbf{~ m}^{-\mathbf{1}}\right)\end{array}$ \\
\hline FR & $1.279 \times 10^{-5}$ & $7.18 \times 10^{-7}$ \\
VR & $0.705 \times 10^{-5}$ & $3.91 \times 10^{-7}$ \\
\hline
\end{tabular}

\subsection{Corrosion Behavior}

Bergant et al. have previously shown that the Ni-based heat-treated coatings exhibit a better corrosion behavior with a factor of 10, when compared to the as-sprayed ones [24]. Thereby, Figure 12 presents the polarization curves of the remelted specimens, while Table 6 shows the corrosion current density $i_{\text {corr }}$ and corrosion potential $E_{\text {corr }}$ estimated using the Tafel extrapolation method. Looking at the $i_{\text {corr }}$, it is important to mention that the VR sample exhibited a lower value than the one obtained in the case of FR sample. Corrosion starts especially in regions with voids, and the process develops faster for the FR compared to the VR samples. Examining the polarization curves, the behavior in the anodic region is similar. The VR sample presents though a slightly longer repasivation plateau between -333 and $-164 \mathrm{mV}$ vs. SCE, while the FR sample indicates a similar, but shorter plateau, between -237 and $-119 \mathrm{mV}$ vs. SCE. A faster and longer repasivation region of the VR specimen shows improved corrosion behavior of the investigated material 
in the tested medium. Starting from $-100 \mathrm{mV}$ vs. SCE up to more positive potentials, the curves overlap on the anodic region, presenting the same corrosion behavior. Figure 13 presents a BSE micrograph of the cross-sectioned corroded VR sample, showing that the $\gamma$-Ni phase dissolved during the corrosion tests, leaving the $\mathrm{Ni}_{3} \mathrm{~B}$ and $\mathrm{CrB}$ blocky phases detaching from the coating.

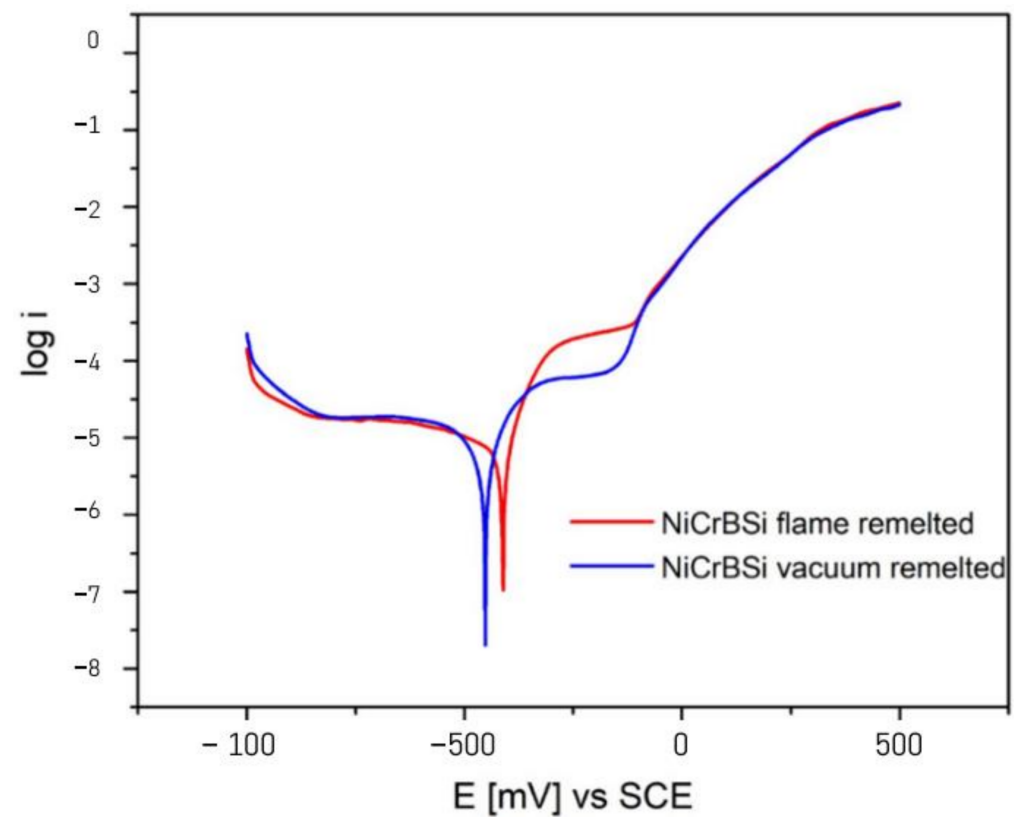

Figure 12. Polarization behavior of the remelted samples.

Table 6. Corrosion current densities and potential of the samples.

\begin{tabular}{ccc}
\hline Sample & $\begin{array}{c}\boldsymbol{i}_{\text {corr }} \\
\left(\mathbf{A ~ c m}^{-2}\right)\end{array}$ & $\begin{array}{c}E_{\text {corr }} \\
(\mathbf{m V})\end{array}$ \\
\hline FR (red) & $0.60 \times 10^{-5}$ & -412 \\
VR (blue) & $0.44 \times 10^{-5}$ & -453 \\
\hline
\end{tabular}

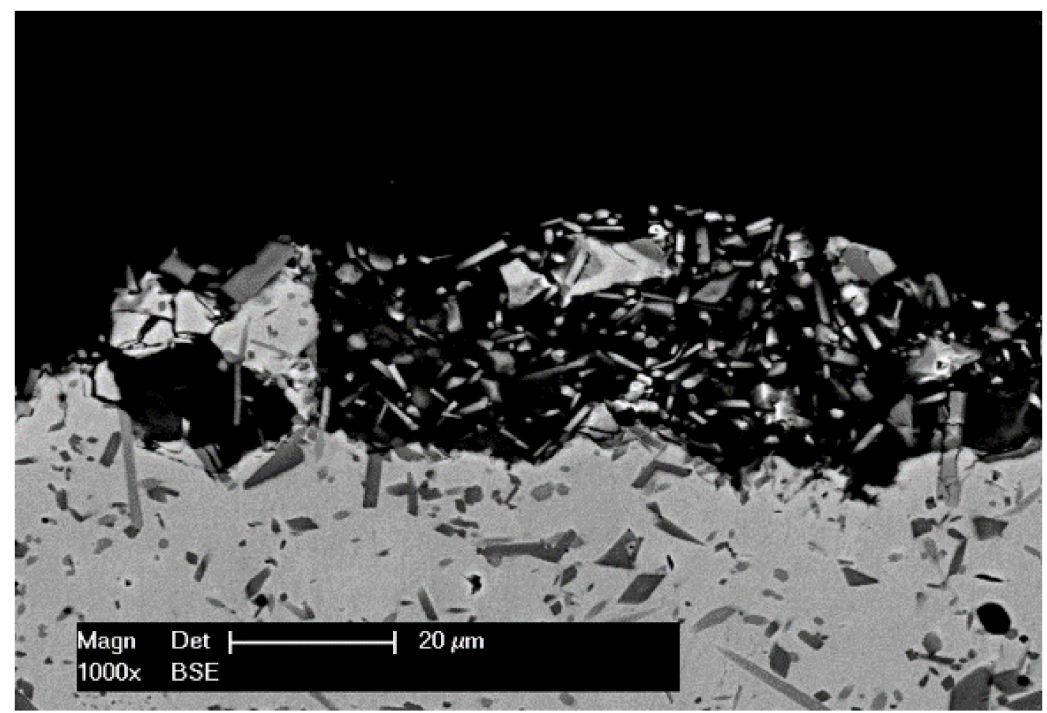

Figure 13. BSE micrograph of the VR corroded sample.

The corrosion potential $E_{\text {corr }}$ presents similar values with a minimal shift of approximately $50 \mathrm{mV}$, presumably due to the different ratios of the phases in the coatings. Minimal 
shifts of up to $100 \mathrm{mV}$ were also observed by Makuch [26] when investigating Ni-based materials with different $\mathrm{Cr}$ content.

\section{Conclusions}

According to the DTA data, the fusing temperature of $1050{ }^{\circ} \mathrm{C}$ (situated approximately $20^{\circ} \mathrm{C}$ under the liquidus temperature of the powder) was applied in a vacuum furnace to obtain a dense coating, with low porosity, satisfying roughness, and a strong metallurgical bond.

Although the HV0.3 microhardness of the flame remelted sample was $12 \%$ higher than that of the vacuum remelted one, the latter displayed a better adhesion to the substrate and it presented a crack-free coating when subjected to HBW indentations, an aspect which reflects a low degree of internal residual stresses, which were eliminated during the thermal post treatment.

The coefficient of friction in the case of vacuum remelted samples had stabilized earlier, offering a longer steady-state period compared to flame remelted specimens. The wear rate of the vacuum remelted sample was almost two times lower than that of the flame remelted one, a fact which can be attributed to the larger amount of hard $\mathrm{CrB}$ and $\mathrm{Ni}_{3} \mathrm{~B}$ phases. The corrosion behavior of the vacuum remelted sample is slightly superior in comparison with the tested flame remelted sample, exhibiting lower current density, especially in the passivation region.

Author Contributions: Conceptualization, N.K., G.M. and V.-A.S.; methodology, N.K., R.M. and D.T.P.; validation R.M., D.T.P., G.M. and V.-A.S,., formal analysis, N.K. and P.C.V.; investigation N.K. and P.C.V., resources, G.M. and V.-A.S.; data curation N.K., P.C.V., R.M. and D.T.P., writingoriginal draft preparation, N.K.; writing-review and editing N.K., R.M., D.T.P., G.M., and V.-A.S,.; visualization N.K.; supervision, G.M. and V.-A.S. All authors have read and agreed to the published version of the manuscript.

Funding: The present work was partially funded through the DAAD (German Academic Exchange Service) program "Research Grant for Doctoral Candidates and Young Academics and Scientist" Ref. no. 91617926. The APC was funded by the Westphalian University of Applied Sciences Gelsenkirchen Bocholt Recklinghausen through the Open Access Publications Fund.

Institutional Review Board Statement: Not applicable.

Informed Consent Statement: Not applicable.

Data Availability Statement: The data reported in this study are available from the authors upon request.

Acknowledgments: We acknowledge the support of the company Karl Schumacher GmbH, Germany, for the sample depositions.

Conflicts of Interest: The authors declare no conflict of interest.

\section{References}

1. Lin, M.C.; Chang, L.S.; Lin, H.C.; Yang, C.H.; Lin, K.M. A Study of High-Speed Slurry Erosion of NiCrBSi Thermal-Sprayed Coating. Surf. Coat. Technol. 2006, 201, 3193-3198. [CrossRef]

2. Houdovka, S.; Vostřák, M.; Hruska, M. Comparison of NiCrBSi Coatings, HVOF Sprayed, Re-Melted by Flame and by HighPower Laser. In Proceedings of the 22nd International Conference on Metallurgy and Materials, Brno, Czech Republic, 15-17 May 2013.

3. Hernández Battez, A.; Viesca, J.L.; González, R.; Blanco, D.; Asedegbega, E.; Osorio, A. Friction Reduction Properties of a CuO Nanolubricant Used as Lubricant for a NiCrBSi Coating. Wear 2010, 268, 325-328. [CrossRef]

4. Paleu, C.C.; Munteanu, C.; Istrate, B.; Bhaumik, S.; Vizureanu, P.; Bălţatu, M.S.; Paleu, V. Microstructural Analysis and Tribological Behavior of AMDRY 1371 (Mo-NiCrFeBSiC) Atmospheric Plasma Spray Deposited Thin Coatings. Coatings 2020, $10,1186$. [CrossRef]

5. Serres, N.; Hlawka, F.; Costil, S.; Langlade, C.; Machi, F. Microstructures and Environmental Assessment of Metallic NiCrBSi Coatings Manufactured via Hybrid Plasma Spray Process. Surf. Coat. Technol. 2010, 205, 1039-1046. [CrossRef]

6. Navas, C.; Colaço, R.; de Damborenea, J.; Vilar, R. Abrasive Wear Behavior of Laser Clad and Flame Sprayed-Melted NiCrBSi Coatings. Surf. Coat. Technol. 2006, 200, 6854-6862. [CrossRef] 
7. Houdková, Š.; Smazalová, E.; Vostřák, M.; Schubert, J. Properties of NiCrBSi Coating, as Sprayed and Remelted by Different Technologies. Surf. Coat. Technol. 2014, 253, 14-26. [CrossRef]

8. Valean, P.-C.; Kazamer, N.; Pascal, D.-T.; Muntean, R.; Baranyi, I.; Marginean, G.; Serban, V.-A. Characteristics of Thermally Sprayed NiCrBSi Coatings before and after Electromagnetic Induction Remelting Process. Acta Polytech. Hung. 2019, 16, 7-18.

9. Sha, J.; Chen, L.-Y.; Liu, Y.-T.; Yao, Z.-J.; Lu, S.; Wang, Z.-X.; Zang, Q.-H.; Mao, S.-H.; Zhang, L.-C. Phase Transformation-Induced Improvement in Hardness and High-Temperature Wear Resistance of Plasma-Sprayed and Remelted NiCrBSi/WC Coatings. Metals 2020, 10, 1688. [CrossRef]

10. Vaithilingam, J.; Goodridge, R.D.; Hague, R.J.M.; Christie, S.D.R.; Edmondson, S. The Effect of Laser Remelting on the Surface Chemistry of Ti6al4V Components Fabricated by Selective Laser Melting. J. Mater. Process. Technol. 2016, 232, 1-8. [CrossRef]

11. Konakov, S.P.; Lyapunov, A.I. Evaluation of the Advantages of Vacuum Heat Treatment. Met. Sci. Heat Treat. 2000, 42, 84-86. [CrossRef]

12. Kim, H.-J.; Hwang, S.-Y.; Lee, C.-H.; Juvanon, P. Assessment of Wear Performance of Flame Sprayed and Fused Ni-Based Coatings. Surf. Coat. Technol. 2003, 172, 262-269. [CrossRef]

13. Kazamer, N.; Vălean, P.; Pascal, D.-T.; Muntean, R.; Mărginean, G.; Serban, V.-A. Development, Optimization, and Characterization of NiCrBSi-TiB2 Flame-Sprayed Vacuum Fused Coatings. Surf. Coat. Technol. 2021, 406, 126747. [CrossRef]

14. Kazamer, N.; Pascal, D.T.; Marginean, G.; Şerban, V.A.; Codrean, C.; Uţu, I.D. A Comparison between Hardness, Corrosion and Wear Performance of APS Sprayed WC-CoMo and WC-Co Coatings. Solid State Phenom. 2016, 254, 71-76. [CrossRef]

15. Bergant, Z.; Grum, J. Porosity Evaluation of Flame-Sprayed and Heat-Treated Nickel-Based Coatings Using Image Analysis. Image Anal. Stereol. 2011, 30, 53-62. [CrossRef]

16. Whitehouse, D. Surfaces and Their Measurement; Kogan Page Science: New York, NY, USA, 2004; ISBN 1903996600.

17. Archard, J.F. Contact and Rubbing of Flat Surfaces. J. Appl. Phys. 1953, 24, 981-988. [CrossRef]

18. Trdan, U.; Grum, J. SEM/EDS Characterization of Laser Shock Peening Effect on Localized Corrosion of Al Alloy in a near Natural Chloride Environment. Corros. Sci. 2014, 82, 328-338. [CrossRef]

19. Davis, J.R. Handbook of Thermal Spray Technology, 1st ed.; ASM International: Novelty, OH, USA, 2004; ISBN 0-87170-795-0.

20. Suffner, J.; Sieger, H.; Hahn, H.; Dosta, S.; Cano, I.G.; Guilemany, J.M.; Klimczyk, P.; Jaworska, L. Microstructure and Mechanical Properties of Near-Eutectic $\mathrm{ZrO}_{2}-60$ wt.\% $\mathrm{Al}_{2} \mathrm{O}_{3}$ Produced by Quenched Plasma Spraying. Mater. Sci. Eng. A 2009, 506, 180-186. [CrossRef]

21. González, R.; García, M.A.; Peñuelas, I.; Cadenas, M.; del Rocío Fernández, M.; Battez, A.H.; Felgueroso, D. Microstructural Study of NiCrBSi Coatings Obtained by Different Processes. Wear 2007, 263, 619-624. [CrossRef]

22. Mrdak, M.R. Microstructure and Mechanical Properties of Nickel-Chrome-Bor-Silicon Layers Produced by the Atmospheric Plasma Spray Process. Vojnoteh. Glas. 2012, 60, 183-200. [CrossRef]

23. Singh, S.; Kaur, M. Mechanical and Microstructural Properties of NiCrFeSiBC $/ \mathrm{Cr}_{3} \mathrm{C}_{2}$ Composite Coatings-Part I. Null 2016, 32, 464-474. [CrossRef]

24. Bergant, Z.; Trdan, U.; Grum, J. Effect of High-Temperature Furnace Treatment on the Microstructure and Corrosion Behavior of NiCrBSi Flame-Sprayed Coatings. Corros. Sci. 2014, 88, 372-386. [CrossRef]

25. Wang, X.; Zhu, L.; Zhou, Z.; Liu, G.; Liu, E.; Zeng, Z.; Wu, X. Tribological Properties of WC-Reinforced Ni-Based Coatings Under Different Lubricating Conditions. J. Therm. Spray Technol. 2015, 24, 1323-1332. [CrossRef]

26. Makuch, N. The Importance of Phase Composition for Corrosion Resistance of Borided Layers Produced on Nickel Alloys. Materials 2020, 13, 5131. [CrossRef] 